\title{
日本人における音楽聴取の心理的機能と個人差
}

\author{
池上 真平 ${ }^{2}$ 昭和女子大学 佐藤 典子 武蔵野音楽大学 羽藤 律 ゆたかカレッジ \\ 生駒 忍 川村学園女子大学 宮澤 史穂 高齢・障害・求職者雇用支援機構 \\ 小西 潤子 沖縄県立芸術大学 星野 悦子 上野学園大学
}

\section{The psychological functions of and individual differences in music listening in Japanese people}

\begin{abstract}
Shimpei Ikegami (Showa Women's University), Noriko Sato (Musashino Academia Musicae), Tadasu Hatoh (Yutaka College), Shinobu Ikoma (Kawamura Gakuen Woman's University), Shiho Miyazawa (Japan Organization for Employment of the Elderly, Persons of Disability and Job Seekers), Junko Konishi (Okinawa Prefectural University of the Arts), and Etsuko Hoshino (Ueno Gakuen University)
\end{abstract}

\begin{abstract}
Regardless of the time and location, people listen to music. One may ask why people listen to music and what function it serves. This study clarifies the psychological functions of listening to music and the attributes associated with the individual differences found in these functions. A total of 916 participants between the ages of 15 and 88 were asked to rate various psychological functions of music listening and Big Five traits. A factor analysis identified the seven factors of psychological functions of music listening: "self-awareness", "emotion regulation", "communication", "tool", "embodiment", "social distance regulation", and "solace". The results revealed that the individual differences in the functions were the result of gender, age, and personality traits. The nature of these seven functions and future directions are discussed.
\end{abstract}

Key words: music listening, psychological functions, gender, age, Big Five traits.

The Japanese Journal of Psychology

J-STAGE Advanced published date: September 30, 2021
約 25 万年以上前に人類に音楽的活動が現れて以来 (Zatorre \& Peretz, 2001), 音楽は人々の生活に広く行 き渡っている。あらゆる音楽的活動のなかでも, 聴取 は広範な人々に支持され，多くの時間とエネルギーと 費用が音楽聴取のために費やされている。それは一体 何故なのだろうか。何が人々を音楽に惹きつけるのだ ろうか。これは心理学における興味深い研究テーマの 1つである。人間が時代や場所や民族を問わず音楽を

Correspondence concerning this article should be send to: Shimpei Ikegami, Department of Psychology, Showa Women's University, Taishido, Setagaya-ku, Tokyo 154-8533, Japan. (E-mail: s-ikegami@ swu.ac.jp)

本研究の一部は青山学院大学教育人間科学研究所研究プロ ジェクトによる助成を受けた。またデータの一部は, 日本音楽 知覚認知学会 2019 年度春季研究発表会および日本心理学会第 83 回・第 84 回大会において発表, 報告された。第 2 著者から第 7 著者までは等しく研究に貢献した。

2 紙面調查の実施に際し, 星野 立子先生 (北海道教育大学函 館校）と安田 孝先生（松山東雲女子大学）に多大なご協力を賜 りました。記して樑く感謝致します。
聴き続けてきたことは, 音楽聴取には人間が必要とす る何らかの機能があることを示唆している。そのよう な機能を明らかにすることは, 人間の音楽的行動への 理解を深めるだけでなく, 音楽的行動について学術的 に探求することの意義にも繋がる重要な問題である。 本研究のリサーチクエスチョンは,「人々が認識する 音楽聴取の心理的機能とはどのようなものか」という ことであり，実証的な調查を行い検討する。なお，本 研究では Merriam (1964 藤井·鈴木訳 1980) に準拠し, 「音楽の機能」という言葉を「音楽を用いる理由と, 特にそれが役立ちうる,より広大な目的に関わるもの」 （p.256）という意味で用いる。

音楽聴取の心理的機能について実証的に探求する主 な方法には, 自由記述を収集するものと, 研究者が用 意した項目への回答から潜在構造を抽出するものがあ る。たとえば Chamorro-Premuzic \& Furnham(2007)は, 43 名の回答者から, 音楽をいつ, なぜ, 聴くのかに ついて自由記述回答を求めて主題分析を実施した。結 果, 15 の機能が見出され, その後潜在的な 3 次元（感 
情制御・調整，理性的鑑賞，背景音楽）に集約された。 一方 Lonsdale \& North（2011）は 30 項目を用意し, 300 人の大学生に「なぜ自分は音楽を聴くのか?」に ついて当てはまる程度を 11 段階で評定させた。因子 分析から 6 つの因子（快気分の処理，気分転換，不快 気分の処理，人間関係，個人的アイデンティティ，監 視）が抽出された。さらに彼らは, 音楽以外の愉しみ・ 余㗇活動である映画, テレビ, スポーツ, 読書, 雑誌 などに関しても同様の質問をして音楽と比較した。そ の結果, 音楽聴取は他の余㗇活動に比べてその働きが 個々人の異なるニーズに対してより高く評定され,「こ の万能性（versatility）が人々にとって音楽がなぜ大変 重要かを説明するかもしれない」(p.108) と指摘した。

音楽聴取の心理的機能に関して, これまで最も徹底 的な概観と検証を行ったのは Schäfer, Sedlmeier, Städtler, \& Huron（2013）である。彼らはまず音楽の 機能, 利用法, 恩恵について明示された膨大な量の過 去の文献を精査して，500を超える機能を集め，その 上でこれらの機能を少ない次元に集約することを試み た。先行研究に基づき 129 項目の質問紙を構成し, 幅 広い年齢のドイッ人 834 名に対して 7 段階で回答を求 め, 主成分分析により潜在的な 3 成分を抽出した。「覚 醒と気分の調整」,「自己認識」,「社会的関係」である。 彼らはこれらを音楽聴取機能のビッグ・スリーと呼ぶ ことを提案した。ただし，これら 3 成分の累積寄与率 は $40 \%$ であり，高くはなかった。

音楽聴取の心理的機能について, 文化間研究も行わ れている。たとえばBoer \& Fischer（2011）は， 7 カ 国にわたる計 222 名の大学生を対象にした自由記述の 分析結果から 7 つの機能 (背景音楽, 記憶, 気晴らし, 感情表現と調節, 自己調節, 自己省察, 社会的結びつ き）を見出し，その上で文化間比較を行った。その結 果, 音楽聴取の心理的機能は文化間で共通点が多い一 方で，相違点も存在することがわかった。

\section{本研究の目的}

以上のように, 音楽聴取の心理的機能については, 質的研究・量的研究の両面から検討されており, 多岐 にわたる機能が見出されてきた。それぞれの研究で提 案された機能の意味内容には類似性もあり, Schäfer et al. (2013)のように先行研究で提案されてきた機能を, 広い年代に共通する少数の主要な次元に集約しょうと する試みもみられる。しかしながら，音楽聴取の心理 的機能の妥当かつ適切な潜在的次元（因子）の数之内 容には，未だ統一見解が存在しない。音楽聴取の主要 な心理的機能を明確にしていくためには, さらなる知 見の蓄積が必要である。そこで本研究は, 網羅的に項 目を設定して調査を行い, 音楽聴取の主要な心理的機 能として妥当な因子を見出した上で, 先行研究結果と の比較検証を行うことを第一の目的とした。調査項目
は，過去の文献の徹底的な展望に基づき調查項目を設 定した Schäfer et al.（2013）から多くを引用すること としたが，厳密な翻訳版調査を行うのではなく，不足 していると考えられた項目を適宜追加し, かつ類似し た項目を削除・統合することで，調査の精緻化を試み ることとした。

ところで，異なる属性をもつ個々人は，同時にいく つかの異なった，しかし相互に関連する音楽の機能を 自らの状況や欲求に合わせて実現していると考えられ る(Clayton, 2016)。しかし, 音楽聴取の心理的機能 の個人差を生む文化以外の要因は，未だ十分に検討さ れていない。Schäfer et al.（2013）の大規模な調查研 究においても, 回答者の属性による違いについては, 検討されていなかった。一般的に, 性別や年齢は, 様々 な個人的属性のなかでも音楽との関わり方に影響する 主な要因であると考えられている（Boer \& Fischer, 2011）。実際に，日本においても音楽への関与の程度 には性別や年代による違いがある（総務省統計局,

2017）。このことから, 性別や年齢は音楽聴取の心理 的機能の個人差をもたらす特に重要な要因なのではな いかと考えられる。具体的には，一般的に女性は男性 よりも感情経験が豊かであるとされ（Barrett, Lane, \& Schwartz, 2000; Brody \& Hall, 2010), 音楽演奏に含ま れる感情表現を大きく評価することから（Kamenetsky, Hill, \& Trehub, 1997), 女性の方が感情に関する機能を 強く認識している可能性がある。また，青年期を対象 にした研究からは, アイデンティティの構築, 感情調 節, 社会的関係の構築に音楽が重要な役割を果たして いることが指摘されており（たとえば, Miranda, 2013; Selfhout, Branje, Bogt, \& Meeus, 2009), 青年期の 人々はこれらに関連する機能を, 他の年代よりも強く 認識していることが示唆される。

さらにパーソナリティ特性も，音楽の好みや関わり 方を左右する要因であることが報告されており (Chamorro-Premuzic \& Furnham, 2007; 星 野, 2015; Rentfrow \& Gosling, 2003), 性別や年齢と同様に音楽 聴取の心理的機能の個人差をもたらす重要な要因の 1 つであると考えられる。たとえば，開放性の高さと内 観を促進するような音楽ジャンルに対する好みとの間 には正の相関があることが報告されており（Rentfrow \& Gosling, 2003), 開放性の高い個人は自己省察を促 進するような音楽聴取の機能を活用する傾向が強いこ とが示唆される。また情緒不安定性が高い個人は, 音 楽を感情的に利用する傾向が強いことから (Chamorro-Premuzic \& Furnham, 2007), 音楽の感情調 節機能をより強く認識していることが示唆される。さ らに外向性が高い個人は, 他者との相互作用に対する 動機づけが高いため, 音楽聴取の社会的機能をより活 用している可能性があるだろう。以上を踏まえ, 本研 究は, 性別, 年代, パーソナリティ特性が, 音楽聴取 
Table 1

分析対象者の性別, 年代のクロス集計表

\begin{tabular}{lrrrrrrrrrr}
\hline 性別 & 10 代 & 20 代 & 30 代 & 40 代 & 50 代 & 60 代 & 70 代 & 80 代 & 無回答 & 計 \\
\hline 女性 & 139 & 181 & 49 & 37 & 26 & 25 & 0 & 1 & 0 & 458 \\
& $30.3 \%$ & $39.5 \%$ & $10.7 \%$ & $8.1 \%$ & $5.7 \%$ & $5.5 \%$ & $0.0 \%$ & $0.2 \%$ & $0.0 \%$ & $100.0 \%$ \\
男性 & 111 & 77 & 24 & 34 & 48 & 49 & 0 & 0 & 1 & 344 \\
& $32.3 \%$ & $22.4 \%$ & $7.0 \%$ & $9.9 \%$ & $14.0 \%$ & $14.2 \%$ & $0.0 \%$ & $0.0 \%$ & $0.3 \%$ & $100.0 \%$ \\
\hline 計 & 250 & 258 & 73 & 71 & 74 & 74 & 0 & 1 & 1 & 802 \\
\hline
\end{tabular}

の心理的機能についての認識にどのような違いをもた らすのかについて明らかにすることを第二の目的とし た。

\section{方法}

\section{調查参加者}

本研究の全調查参加者は, 916 名（女性 511 名, 男 性 398 名, 性別無回答 7 名）であった。参加者の年齢 は 15-88 歳で年代構成は 10 代 293 名, 20 代 310 名, 30 代 76 名, 40 代 74 名, 50 代 78 名, 60 代 75 名, 80 代 1 名, 無回答 9 名であった。調査参加者のうち 596 名は紙面調查に参加し, 残りの 320 名は Web 調查に 参加した。

調査参加者のうち，音楽聴取の心理的機能について の項目に回答漏れや重複回答があった者, 適切に回答 していないと判断された者, 出身地を国外と回答した 者を除いて，802名による回答を分析の対象とした。 分析対象者の性別，年代のクロス集計表を Table 1 に 示す。この他，分析ごとに久損のないデータのみを用 いて分析した。

\section{調査内容}

属性 性別，年齢（数值での回答に抵抗がある場合 には，選択肢のなかから選ぶよう求めた）, 居住地, 出身地などを尋ねた。

音楽聴取の心理的機能 まず Schäfer et al.（2013） の責任著者から, 彼らの調查項目を翻訳して一部の項 目を使用して調査を実施する許可を得た上で，彼らが 用いた全 129 項目を翻訳した。このとき，できる限り 原文の意味を損なわないように，かつ日本語として理 解しやすいように配慮した。一部の項目は, 英語のネ イティヴ話者に確認し，訳が正確になるようにした。 その後第一著者を含む 6 名で合議を行い, 意味内容が 似ている項目や回答しにくいと判断された 22 項目を 除いた。さらにこれらとは別に，日本における音楽聴 取の心理的機能を測定するために必要と判断された 26 項目を加え, 計 133 項目とした。なお，本調査に 先立ち大学生 29 名を対象に予備調查を行い, 意味が とりにくいとの指摘があった 2 項目の表現を修正し
て，最終的な項目を確定した。教示では「音楽を聴く ことにはどのような心理的な機能があるのかというこ とについて尋ねる」ことを明示した上で，「あなたは なぜ音楽を聴きますか？」と尋ね，各項目について当 てはまる程度を 0 点一 6 点の 7 段階で回答を求めた。 回答にあたっては，どのような音楽や聴取状況を思い 浮かべても構わない旨を明示した。

パーソナリティ 日本語版 Ten Item Personality Inventory（TIPI-J; 小塩・阿部・カトローニ，2012）を 用いた。この尺度は Big Five 特性（外向性, 協調性, 誠実性，情緒不安定性，開放性）を各 2 項目の計 10 項目で測定する 7 件法の尺度である。本研究の調査項 目は，音楽聴取の心理的機能だけで 133 あるため，少 しでも参加者の負担を軽くするために，項目数が少な く，かつ十分な妥当性・信頼性が示されている同尺度 を用いた。

\section{調査手続き}

本研究は青山学院大学人を対象とする研究倫理審査 を受け，承認を得てから実施された（承認番号：青 18-19)。紙面調査は，回答者の居住地域が偏らないよ うに配慮して, 北海道, 茨城県, 東京都, 神奈川県, 千葉県, 大阪府, 愛媛県, 福岡県, 沖縄県の 9 都道府 県において実施した。ただし，紙面調査の参加者の大 半は大学生であったため, 年代に偏りがみられた。そ こで,より幅広い年代の回答者も対象にできるように, 紙面調查に加えて Web 調查も行った。紙面調查・ Web 調查ともに, 調查参加者に研究の目的などにつ いて説明し，参加に同意する場合にのみ調查に回答す るよう求めた。

\section{結果}

\section{音楽聴取の心理的機能の因子}

分析対象者 (802 名) $\times$ 調查項目 (133 項目) の行列 に対して最小二乗法・プロマックス回転による因子分 析を行った。平行分析を行ったところ，7因子構造が 妥当と判断された。因子の解釈可能性に優れ，軸の回 転前の累積寄与率が $51.5 \%$ と $50 \%$ を上回っていたこ とから,この 7 因子構造を採用した ${ }^{3}$ 。因子負荷行列 
の一部を Table 2 に示す。

第 1 因子は「音楽は自分自身の道を見つけるのを助 けてくれるから」,「音楽は自分自身について学ぶのを 助けてくれるから」などの負荷量が高く，「自己認識」 因子と解釈した。第 2 因子は「音楽は私の気分を明る くすることができるから」，「私は音楽を聴くことに喜 びを感じるから」などの負荷量が高く，「感情調節」 因子と解釈した。第 3 因子は「音楽は友人たちとの話 題にできるものだから」,「音楽は友達と繋がっている と感じさせてくれるから」などの負荷量が高く，「コ ミュニケーション」因子と解釈した。第 4 因子は「私 の周りの雑音を音楽でかき消したいから」,「音楽は朝 私を起こすのを助けてくれるから」,「音楽は私が眠り につくのを助けてくれるから」などの負荷量が高く， 「道具的活用」因子（以下，「道具」因子とする）と解 釈した。第 5 因子は「音楽を聴くと身体を動かしたく なるから」，「音楽が引き起こす身体の変化が好きだか ら（心拍の変化や皮膚がムズムズする感じなど）」な どの負荷量が高く，「身体性」因子と解釈した。第 6 因子は「音楽は世界のことをもっと理解させてくれる から」,「音楽は現実や周りの世界を忘れさせてくれる から」などの負荷量が高く,「社会的距離調節」因子 (以 下，「距離調節」因子とする）と解釈した。第 7 因子 は「音楽は私の悲しみに寄り添ってくれるから」，「音 楽は悲しい時に私を慰めてくれるから」などの負荷量 が高く，「慰め」因子と解釈した。

\section{性別・年代による違い}

性別や年代によって, 音楽聴取の心理的機能がどの ように異なるのかを検討するために，因子ごとに各参 加者の因子得点を Bartlett 法により算出した。性別, 年代ごとの平均值と標準誤差を Figure 1 に示す。なお, 60 代以上は人数が少なかったため, 「60 代以上」とい う 1 つのカテゴリにまとめた。Figure 1 より，全体的 に性別や年代による違いがあり，10 代や 20 代の得点 が高い傾向があることがみてとれる。7因子の因子得 点を従属変数として性別 $\times$ 年代の多変量分散分析を 行った。その結果, 性別の主効果 (Pillai's Trace $=.05$, $\left.F(7,783)=5.57, p<.001, \eta_{\mathrm{p}}{ }^{2}=.047\right) \quad$ と年代の主効果 $($ Pillai's Trace $=.30, F(35,3935)=7.15, p<.001$, $\left.\eta_{\mathrm{p}}{ }^{2}=.060\right)$ が有意であった。続いて, 因子ごとに因子 得点を従属変数として性別 $\times$ 年代の 2 要因分散分析を

\footnotetext{
3 なお，因子数決定にあたっては，他の因子数も検討した。因 子数を Schäfer et al. (2013) が採用した 3 因子構造に指定して分 析を行ったところ, 大まかには「自己認識」,「感情調節」,「社 会的関係性」と命名しうる因子構造が得られたものの, 個々の 項目に着目すると, 当てはまりが悪いものが複数みられた。一方, 固有值 1 以上を基準とした場合には 18 因子が抽出されたが，一 部因子の解釈が不可能であった。以上を総合的に考慮し， 7 因子 構造を採用した。
}

行って検討したところ，「自己認識」因子は性別の主 効果が有意であり $(F(1,789)=9.33, p<.01$, $\left.\eta_{\mathrm{p}}{ }^{2}=.012\right)$ ，女性の方が高かった。年代の主効果も有 意であり $\left(F(5,789)=5.63, p<.01, \eta_{\mathrm{p}}{ }^{2}=.034\right)$, 多重比 較 (Bonferroni 法) の結果, 10 代は 30 代, 40 代, 50 代, 60 代よりも有意に高く $(p \mathrm{~s}<.05), 20$ 代は 30 代, 50 代, 60 代よりも有意に高かった $(p \mathrm{~s}<.05)$ 。「感情調節」 因子も性別の主効果が有意であり $(F(1,789)=28.35$, $\left.p<.001, \eta_{\mathrm{p}}{ }^{2}=.035\right)$, 女性の方が高かった。年代の主 効果も有意であり $(F(5,789)=28.60, p<.001$, $\left.\eta_{\mathrm{p}}{ }^{2}=.153\right), 10$ 代と 20 代はそれぞれ他のどの年代よ りも有意に高かった $\left(p_{\mathrm{s}}<.001\right)$ 。「コミュニケーショ ン」因子は年代の主効果のみが有意であり $(F(5$, $\left.789)=4.85, p<.001, \eta_{\mathrm{p}}{ }^{2}=.030\right), 10$ 代は 30 代, 50 代, 60 代よりも有意に高く, 20 代は 50 代よりも有意に高 かった $\left(p_{\mathrm{S}}<.05\right)$ 。「道具」因子は年代の主効果のみ が有意であり $\left(F(5,789)=14.46, p<.001, \eta_{\mathrm{p}}{ }^{2}=.084\right)$ ， 10 代と 20 代はそれぞれ他のどの年代よりも有意に高 かった $\left(p_{\mathrm{s}}<.05\right)$ 。「身体性」因子は性別と年代の主 効果㧍よび交互作用はいずれも有意ではなかった。距 離調節」因子は性別の主効果が有意であり $(F(1$, $\left.789)=8.10, p<.01, \eta_{\mathrm{p}}{ }^{2}=.010\right)$ ，女性の方が高かった。 年代の主効果も有意であり $(F(5,789)=3.63, p<.01$, $\left.\eta_{\mathrm{p}}{ }^{2}=.023\right), 10$ 代は 60 代よりも有意に高く, 20 代は 50 代， 60 代よりも有意に高かった $(p \mathrm{~s}<.05)$ 。「慰め」 因子は性別の主効果のみが有意であり $(F(1$, 789) $\left.=17.09, p<.01, \eta_{\mathrm{p}}{ }^{2}=.021\right)$ ，女性の方が高かった。

\section{パーソナリティとの関連}

パーソナリテイが音楽聴取の心理的機能を説明しう るかどうかについて検討するために, 外向性, 協調性, 誠実性, 情緒不安定性, 開放性の尺度得点, 性別（女 性を 0 ，男性を 1 として投入), 年代を説明変数, 因 子得点を目的変数とする重回帰分析（強制投入法）を 因子ごとに行った。性別と年代を説明変数に加えたの は, 標準偏回帰係数を比較することにより，パーソナ リティが性別や年代と比べてどの程度大きな影響力を もつかについて推定できると考えたからであった。な お VIF は最大でも 1.28 であり, 多重共線性の問題は ないと判断した。決定係数と標準偏回帰係数を Table 3 に示す。Table 3 より, 性別・年代と同程度かそれ以 上の標準偏回帰係数を示した Big Five 特性があること がみてとれ，パーソナリティも音楽聴取の心理的機能 の認識に影響することを示している。ただし，本研究 はサンプルサイズが大きく，小さな係数でも統計的に は有意になるため, 結果の解釈には留意が必要であろ う。

「自己認識」因子は, 開放性 $(\beta=.30, p<.001)$ が 正の説明力を示した一方で, 年代 $(\beta=-.18, p<.001)$ と性別 $(\beta=-.15, p<.001)$ が負の説明力を示した。「感 
Table 2

因子負荷行列の一部

\begin{tabular}{|c|c|c|c|c|c|c|c|}
\hline 項目 & F1 & $\mathrm{F} 2$ & F3 & F4 & F5 & F6 & F7 \\
\hline 音楽は自分自身の道を見つけるのを助けてくれるから & .80 & .00 & -.03 & .00 & -.07 & .01 & .16 \\
\hline 私はその音楽について何かを見つけ出したいから & .75 & -.02 & .02 & -.01 & -.01 & .02 & .05 \\
\hline 自分の音楽活動（演奏や歌唱など）に役立てたいから & .72 & -.10 & .07 & -.08 & .08 & -.02 & -.18 \\
\hline その音楽について学びたいから & .71 & -.02 & .09 & .01 & .04 & .07 & -.24 \\
\hline 音楽は私の美的感覚に訴えるから & .71 & .17 & -.15 & -.01 & .11 & -.01 & -.12 \\
\hline 音楽は自分自身について学ぶのを助けてくれるから & .70 & -.07 & .04 & -.04 & -.02 & .05 & .17 \\
\hline 音楽は私の気分を明るくすることができるから & -.13 & .82 & .10 & -.02 & .09 & -.15 & .13 \\
\hline 私は音楽を聴くことに喜びを感じるから & .06 & .82 & .00 & .05 & -.01 & .01 & -.11 \\
\hline 音楽は気晴らしになるから & -.18 & .77 & .07 & .12 & -.03 & -.15 & .07 \\
\hline 音楽は素敵な娛楽だから & .09 & .76 & .07 & .12 & -.12 & -.09 & -.10 \\
\hline 音楽は私に心地良さをもたらしてくれるから & .11 & .73 & -.07 & .06 & -.02 & -.12 & .05 \\
\hline 音楽は私の気分を高揚させることができるから & -.04 & .72 & .04 & -.01 & .16 & .01 & -.03 \\
\hline 音楽は友人たちとの話題にできるものだから & -.02 & .17 & .73 & .10 & -.05 & -.04 & .02 \\
\hline 音楽は友達と繋がっていると感じさせてくれるから & .08 & -.06 & .71 & -.06 & -.02 & .19 & .14 \\
\hline 友人たちも私と同じ音楽が好きだから & -.05 & -.02 & .70 & .16 & .02 & .11 & .03 \\
\hline 音楽は私の友人たちも聞くのを好むものだから & -.18 & .10 & .67 & .03 & .06 & .27 & -.01 \\
\hline 自分と同じような音楽の好みを持つ人たちと親しくなるのを助けてくれるから & .14 & .16 & .65 & .02 & -.01 & -.10 & .08 \\
\hline 音楽は私の記憶を友人たちと共有する手段だから & .00 & -.04 & .63 & -.12 & .06 & .26 & .08 \\
\hline 私の周りの雑音を音楽でかき消したいから & -.03 & .31 & -.06 & .58 & -.15 & .05 & .04 \\
\hline 音楽は私が他の事柄をするあいだに，退屈するのを防いでくれるから & -.08 & .44 & .16 & .50 & -.12 & -.08 & .05 \\
\hline 私は音楽で時間つぶしができるから & -.16 & .35 & .19 & .50 & -.15 & .00 & -.04 \\
\hline 音楽が鳴っていないと落ち着かないから & .25 & .16 & -.05 & .49 & .04 & .10 & -.12 \\
\hline 私は他の事柄をしているあいだ, 背景に音楽が必要だから & .10 & .31 & .07 & .42 & .04 & .01 & -.04 \\
\hline 大音量で聴くのが好きだから & .09 & .23 & .02 & .40 & .16 & .05 & -.16 \\
\hline 音楽を聴くと身体を動かしたくなるから & -.08 & .47 & .07 & -.05 & .52 & .10 & -.13 \\
\hline 私は音楽に合わせて踊ることができるから & .19 & .11 & .17 & -.05 & .50 & -.12 & -.08 \\
\hline 私は新しい動きや振りを試してみたくなるから & .34 & .01 & .15 & .01 & .46 & -.14 & -.02 \\
\hline 音楽が引き起こす身体の変化が好きだから (心拍の変化や皮膚がムズムズする感じなど) & .08 & .25 & -.05 & -.13 & .40 & .26 & -.16 \\
\hline 音楽は私を出かけたい気分にさせてくれるから & .01 & .15 & .11 & .05 & .38 & .13 & .19 \\
\hline 音楽は私がするスポーツにふさわしいから & .08 & -.09 & .29 & .03 & .36 & .01 & .04 \\
\hline 音楽は私の信仰心を支えてくれるから & .02 & -.18 & .20 & .07 & .23 & .51 & -.04 \\
\hline 音楽は世界のことをもっと理解させてくれるから & .38 & -.01 & .14 & -.03 & -.05 & .50 & -.08 \\
\hline 音楽は他の人たちがどのように考えるかを教えてくれるから & .30 & -.04 & .36 & .01 & -.18 & .43 & -.01 \\
\hline 音楽は現実や周りの世界を忘れさせてくれるから & .02 & .31 & -.11 & .27 & -.03 & .42 & -.01 \\
\hline 他の人たちについて学ぶことができるから & .35 & -.04 & .33 & -.03 & -.17 & .41 & -.01 \\
\hline 音楽はある集団に自分が属しているということを示してくれるから & .14 & -.19 & .39 & .04 & .15 & .41 & -.10 \\
\hline 音楽は私の悲しみに寄り添ってくれるから & .32 & .09 & .10 & .01 & -.12 & -.06 & .55 \\
\hline 音楽は悲しい時に私を慰めてくれるから & .19 & .29 & .04 & .01 & -.03 & -.10 & .47 \\
\hline 音楽は過去の記憶を思い出させてくれるから & .16 & .26 & .22 & -.12 & .05 & -.20 & .35 \\
\hline 音楽を聴いて泣きたいから & .14 & -.07 & .12 & .15 & .11 & .03 & .34 \\
\hline 音楽は私の気持ちや気分を映し出してくれるから & .29 & .31 & .05 & -.07 & .04 & .01 & .34 \\
\hline 音楽は特定の人物を思い起こさせるから & .27 & .00 & .30 & .00 & -.02 & -.01 & .33 \\
\hline
\end{tabular}

注）因子ごとに負荷量順に上位 6 項目を抜粋し掲載した。全項目の因子負荷行列は電子付録に掲載した。 
情調節」因子は, 開放性 $(\beta=.18, p<.001)$ と協調性 $(\beta=.16, p<.001)$ と情緒不安定性 $(\beta=.12, p<.01)$ が正の説明力を示した一方で, 年代 $(\beta=-.32$, $p<.001)$ と性別 $(\beta=-.16, p<.001)$ が負の説明力を 示した。「コミュニケーション」因子は, 外向性 $(\beta=.20$, $p<.001)$ と協調性 $(\beta=.11, p<.01)$ と誠実性 $(\beta=.08$,
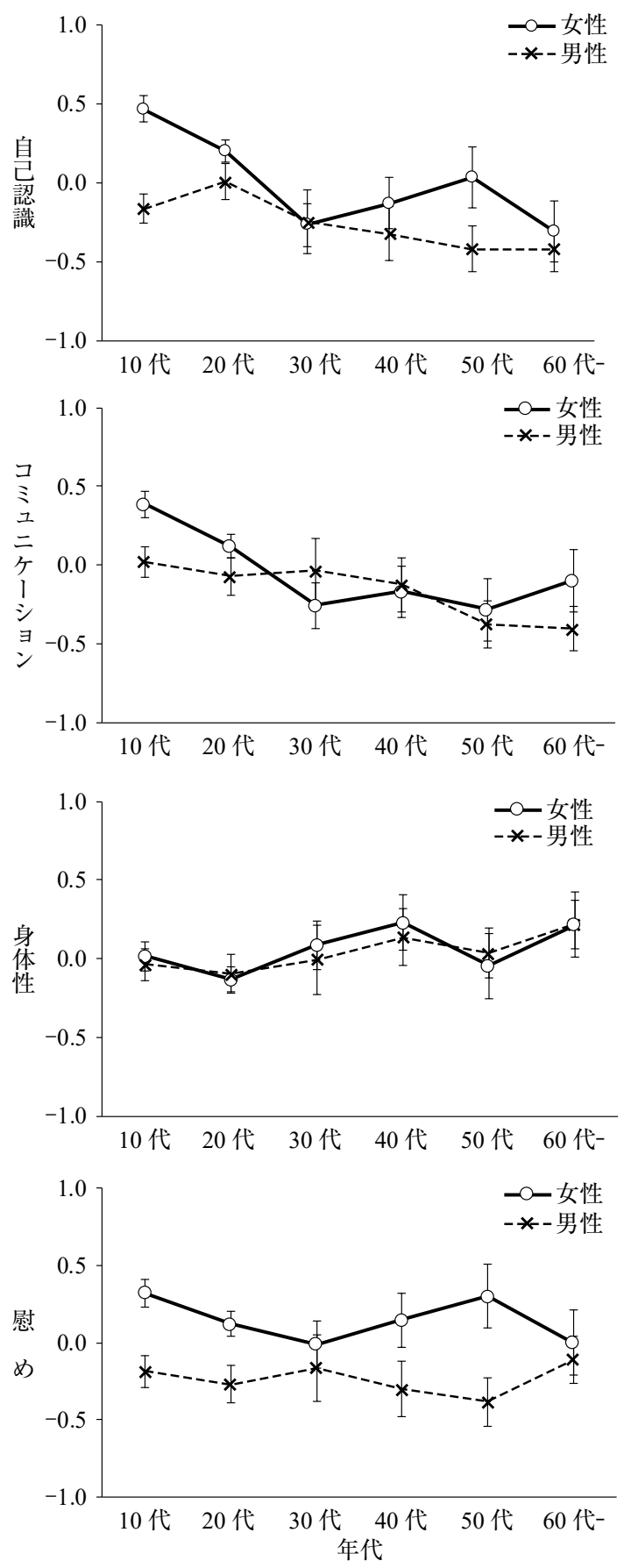

$p<.05)$ が正の説明力を示した一方で, 年代 $(\beta=-.21$, $p<.001 ）$ が負の説明力を示した。「道具」因子は, 年 代 $(\beta=-.28, p<.001)$ と協調性 $(\beta=-.09, p<.05)$ が 負の説明力を示した。「身体性」因子は, 開放性 $(\beta=.16$, $p<.001)$ と外向性 $(\beta=.08, p<.05)$ が正の説明力を 示した。「距離調節」因子は, 開放性 $(\beta=.21$,
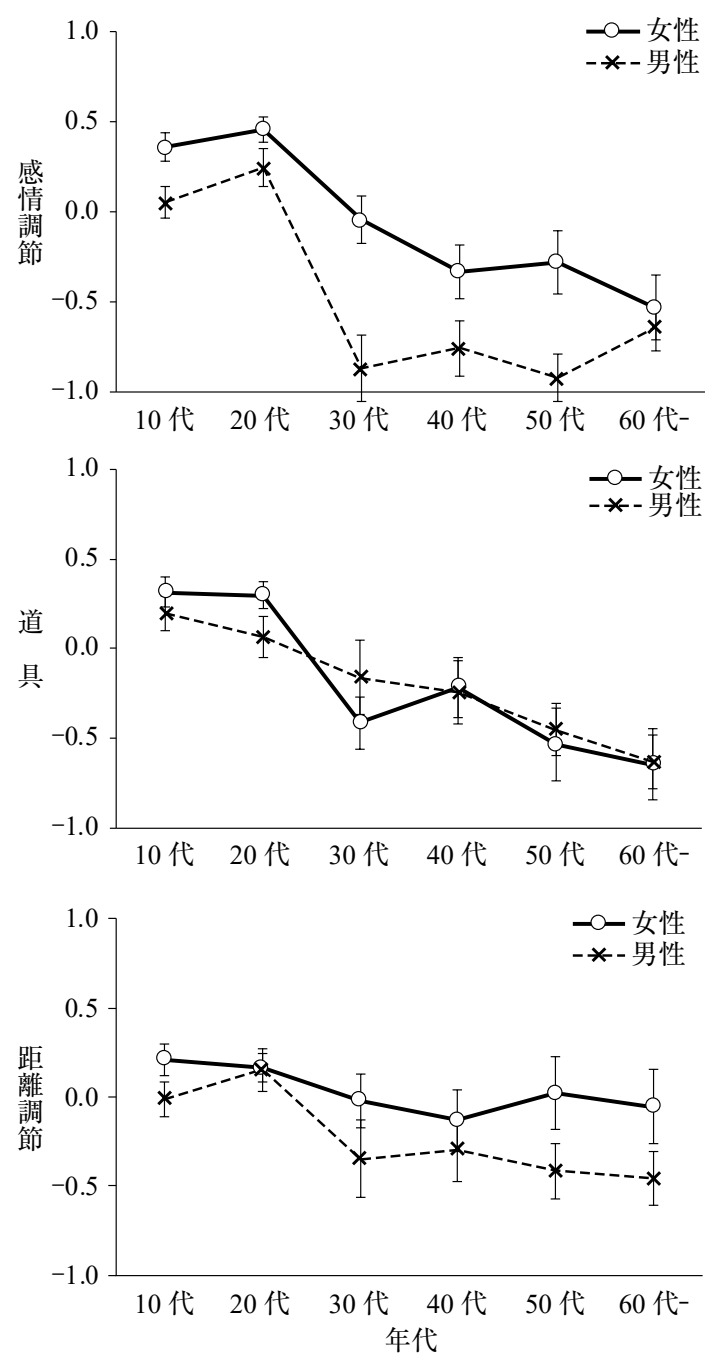

Figure 1. 性別・年代ごとの各因子の因子得点（エラーバーは標準誤差）。 
Table 3

因子得点を目的変数とした重回帰分析結果

\begin{tabular}{|c|c|c|c|c|c|c|c|c|}
\hline 説明変数 & & 自己認識 & 感情調節 & $\begin{array}{c}コ ミ ュ ニ \\
\text { ケーション }\end{array}$ & 道具 & 身体性 & 距離調節 & 慰め \\
\hline \multirow[t]{2}{*}{ 性別 } & $\beta$ & $-.15 * * *$ & $-.16^{* * *}$ & -.05 & -.05 & .02 & $-.10 * *$ & $-.15^{* * *}$ \\
\hline & $r$ & $-.19 * * *$ & $-.24 * * *$ & $-.11 * *$ & $-.09 * *$ & .01 & $-.12 * * *$ & $-.19 * * *$ \\
\hline \multirow[t]{2}{*}{ 年代 } & $\beta$ & $-.18 * * *$ & $-.32 * * *$ & $-.21 * * *$ & $-.28 * * *$ & .06 & $-.14 * * *$ & -.03 \\
\hline & $r$ & $-.20 * * *$ & $-.36^{* * *}$ & $-.19 * * *$ & $-.30 * * *$ & $.07 *$ & $-.16 * * *$ & $-.06^{*}$ \\
\hline \multirow[t]{2}{*}{ 外向性 } & $\beta$ & -.00 & .04 & $.20 * * *$ & -.05 & $.08^{*}$ & $-.09 *$ & -.01 \\
\hline & $r$ & $.12 * * *$ & $.07 *$ & $.21 * * *$ & -.03 & $.14 * * *$ & -.00 & .02 \\
\hline \multirow[t]{2}{*}{ 協調性 } & $\beta$ & -.01 & $.16^{* * *}$ & $.11^{* *}$ & $-.09 *$ & -.03 & -.04 & .03 \\
\hline & $r$ & -.01 & $.11 * *$ & $.08 * *$ & $-.10 * *$ & -.02 & -.03 & .02 \\
\hline \multirow[t]{2}{*}{ 誠実性 } & $\beta$ & .05 & -.04 & $.08^{*}$ & .02 & .05 & .05 & $.09 *$ \\
\hline & $r$ & .03 & $-.10 * *$ & $.07 *$ & $-.08 *$ & $.09^{* *}$ & .01 & .04 \\
\hline \multirow[t]{2}{*}{ 情緒不安定性 } & $\beta$ & .05 & $.12 * *$ & .05 & .02 & .05 & .06 & $.16^{* * *}$ \\
\hline & $r$ & .05 & $.16^{* * *}$ & .00 & $.09 * *$ & -.02 & $.08 *$ & $.15^{* * *}$ \\
\hline \multirow[t]{2}{*}{ 開放性 } & $\beta$ & $.30 * * *$ & $.18^{* * *}$ & .05 & .05 & $.16^{* * *}$ & $.21 * * *$ & $.08^{*}$ \\
\hline & $r$ & $.30^{* * *}$ & $.17 * * *$ & $.13 * * *$ & .03 & $.20 * * *$ & $.17 * * *$ & $.07 *$ \\
\hline$R^{2}$ & & $.16^{* * *}$ & $.23 * * *$ & $.11 * * *$ & $.10 * * *$ & $.05 * * *$ & $.08 * * *$ & $.06^{* * *}$ \\
\hline
\end{tabular}

$p<.001)$ が正の説明力を示した一方で, 年代 $(\beta=-.14$, $p<.001)$ と性別 $(\beta=-.10, p<.01)$ と外向性 $(\beta=-.09$, $p<.05 ）$ が負の説明力を示した。「慰め」因子は，情 緒不安定性 $(\beta=.16, p<.001)$ と誠実性 $(\beta=.09$, $p<.05)$ と開放性 $(\beta=.08, p<.05)$ が正の説明力を示 した一方で, 性別 $(\beta=-.15, p<.001)$ が負の説明力 を示した。

\section{考察}

本研究は，今日の日本における音楽聴取の心理的機 能の因子と，その機能の強さの程度に個人差をもたら しうる要因について検討した。結果より, 音楽聴取の 心理的機能は 7 つの機能 (自己認識, 感情調節, コミュ ニケーション, 道具的活用, 身体性, 社会的距離調節, 慰め)によって整理可能であること，さらにそれらの 機能の個人差の一部は, 年代, 性別, パーソナリティ によって説明可能であることが示された。以下，因子 ごとに考察する。

\section{自己認識}

「自己認識」は，自分自身に関して考えることを促 進する音楽聴取の機能であり, 現在の自己に対する理 解を深めることや将来の自己像を形成することなどが 含まれる。先行研究でも Schäfer et al.（2013）による 同名の因子の他に,「自己省察」(Boer \& Fischer, 2011)，「個人的アイデンティティ」(Lonsdale \& North, 2011),「アイデンティティと自己理解」(Hays \& Minichiello, 2005）といった同様の因子が抽出されき
た。音楽聴取はアイデンティティ形成と密接に関わっ ていると考えられており（たとえば，Miranda, 2013), 本研究の結果はこの考えをさらに支持するも のといえる。

個人差については，年代間の比較では 10 代，20 代 が自己認識の機能を強く認識していた。このことは, アイデンティティの形成は一般に青年期もしくは成人 形成期の課題であることと矛盾しない。性別の比較で は女性の方が自己認識機能を強く認識していたが，こ れは音楽への関与度の違いによって説明できる。すな わち，女性の方が男性よりも音楽への関与度が高い傾 向にあるため（総務省統計局，2017）, 自己認識にも 音楽を活用する程度が大きいのではないかと考えられ る。パーソナリティについては, 開放性の高さとの関 連が示された。開放性の高い個人は自己省察をする傾 向そのものが強いため（Trapnell \& Campbell, 1999), 音楽の自己認識機能も活用する機会が多いのではない かと考えられる。

\section{感情調節}

「感情調節」は，個人にとって望ましい気分や感情 体験をもたらすような音楽聴取の機能であり, 同様の 機能はこれまでも複数の研究によって見出されてきた (Boer \& Fischer, 2011; Chamorro-Premuzic \& Furnham, 2007; Hays \& Minichiello, 2005; Schäfer et al., 2013)。音 楽は感情を聴取者に伝え, 実際に感情を喚起させる (Juslin \& Västfjäll, 2008)。人間はそのことを利用して, 感情調節に音楽聴取を用いるものと考えられる。 
個人差については，女性の方が男性よりも「感情調 節」の得点が高かった。このことは女性の方が男性よ りも感情的欲求を満たすために音楽を聴くことを報告 した North, Hargreaves, \& O'Neill（2000）と一致する。 この性差は, 自己認識と同様に音楽への関与度の違い によって説明可能であろう。さらに，一般に女性は男 性よりも感情経験が豊かであると考えられており (Brody \& Hall, 2010)，この考えを支持する研究もある (Barrett, Lane, \& Schwartz, 2000)。音楽聴取においても 女性の方が男性よりも演奏に含まれる感情表現を大き く評価すること（Kamenetsky, Hill, \& Trehub, 1997）が 示されており，このような感情経験の性差が, 音楽聴 取の「感情調節」機能の認識にも違いをもたらしたの ではないかと考えられる。年代については 10 代, 20 代の值が高く, 30 代以降は因子得点が急減したが, これは加齢につれて感情が安定していくことによるも のと考えられる (Brose, Scheibe, \& Schmiedek, 2013)。 パーソナリテイについては「自己認識」の場合と同様 に, 開放性が高いほど感情調節の機能を強く認識して いた。開放性の高い人物は自身の感情に対する感度が 高いことから (John \& Gross, 2006), 音楽聴取の感情 調節機能を享受しやすいと考えられる。さらに情緒不 安定性が高いほど感情調節の機能を強く認識してい た。これは，この特性が感情面では不安定でストレス を感じやすいことから, 安定した感情状態を経験する ために音楽聴取を活用するものと考えられる。

\section{コミュニケーション}

「コミュニケーション」は，他者との関係を促進す るような音楽聴取の機能である。Schäfer et al. (2013) の「社会的関係性」のうち, 特に身近な他者との関係 を良好にするような機能が独立して抽出されたものと 考えられる。その他の研究でも同様の機能が見出され ている（Boer \& Fischer, 2011; Hays \& Minichiello, 2005; Lonsdale \& North, 2011)。年代については, 10 代や 20 代はこの機能を強く認識していたが，これは青年期に おいて音楽聴取は友人との関係形成に重要な役割を果 たすこと（Selfhout, Branje, Bogt, \& Meeus, 2009）と一 致する。さらに，個人の対人関係の範囲は，20代ま では広がるが 30 代以降は減少に転じ, 親密な他者と の関係に集約されていく（Wrzus, Hänel, Wagner, \& Neyer, 2013)。音楽聴取のコミュニケーション機能に 対する認識も，このような対人関係の範囲とよく対応 しているといえる。パーソナリティについては外向性 との関連が認められた。外向性が高い個人は, 他者と の相互作用に対する動機づけが高いため, コミュニ ケーションに音楽聴取を活用する程度も高かったもの と考えられる。

\section{道具的活用}

「道具」は, 音楽を行動の背景として聴取し, 杂隹音 をかき消す，退屈を防ぐ，時間をつぶす，起床や就寝 を助けるといった目的を達成するための道具としての 機能である。これは Boer \& Fischer（2011）や Schäfer, Tipandjan, \& Sedlmeier (2012) の「背景」機能とお拉 よそ対応している。「道具」因子に負荷量が高かった 項目のいくつかは, Schäfer et al.（2013）では「覚醒・ 気分調整」機能に含まれていた。また背景音楽として の音楽聴取を気分調整の 1 つと捉える立場もある (Saarikallio, 2012)。これらのことは, 背景としての音 楽聴取が感情調節と関わりが深いことを示唆してい る。音楽聴取を「道具」として活用するためには, 音 楽聴取の機能についてメ夕認知を働かせることが有効 であるので，道具機能が音楽聴取の他の機能と不可分 であることは，自然であるように思われる。ただし，

「感情調節」は, 音楽そのものを目的とする聴取によっ て生じる機能であるのに対し，「道具」は，音楽その ものを必ずしも目的としない聴取によって生じる機能 であるいう点で異なると考えられる。

個人差については, 10 代 20 代の得点が高かった。 10 代 20 代は感情調節の機能を強く認識しているため, 道具としても活用する機会も多くなるものと考えられ る。

\section{身体性}

「身体性」は，身体運動を動機づけたり，身体反応 を生じさせたり，体調を良く感じさせたりする機能で あった。音楽，特にリズム面は身体運動と深い関わり があり，たとえば音楽聴取により身体運動を動機づけ られることは多くの人が経験する（Madison, 2006）。 さらに音楽聴取によって喚起される強烈な感情は, 多 様な身体反応を引き起こす (Juslin \& Västfjäll, 2008)。 このようなことからも身体性は音楽聴取に欠かすこと のできない機能であることがみてとれる。「身体性」 因子は 7つの因子のなかでは唯一性別や年代による違 いが認められなかったことから，「身体性」は年代や 性別を問わない普遍的な機能であるといえるだろう。 パーソナリティについては, 開放性や外向性との関連 が示された。Luck, Saarikallio, Burger, Thompson, \& Toiviainen（2010）は開放性や外向性の高い個人は音 楽聴取によって生じる身体の動きも大きいことを示し ており, 本研究結果と整合性が高い。

\section{社会的距離調節}

「社会的距離調節」は, 外的世界と自己の距離を調 節する機能を指す。音楽聴取を通して他者や世界のこ とを理解しようとしたり, 反対に他者・社会から離れ， たとえば現実逃避をしたりすることが含まれる。 
Lonsdale \& North（2011） は他者や世界についての理 解を促進するような因子を「監視」と呼び, Boer \& Fischer（2011）は音楽聴取による現実逃避を「自己調 節」機能に含めた。対して本研究では, 社会への「接 近」と「回避」を含む両価的でダイナミックな機能と して抽出され, 日本人独自の機能である可能性がある。 集団への同調圧力が強いとされる日本の社会（山本, 1977）において, 個人は社会との距離をコントロール するために音楽を活用するのかもしれない。なお，個 人差については, 開放性が特に強い関連を示しており, 社会や世界のことを理解しようとする傾向，および権 威への疑問や柔軟な価值観 (小塩, 2010) が反映され たものとも考えられる。

\section{慰 め}

「慰め」は, 気分の落ち込みの解消に貢献するよう な音楽聴取の機能である。人は気分が落ち込んだ時に 悲しい音楽を聴く傾向があり（Millgram, Joormann, Huppert, \& Tamir, 2015), 悲しい音楽の聴取は快感情 をもたらす（たとえば, Vuoskoski, Thompson, McIlwain, \& Eerola, 2012)。こうした悲しい音楽の聴取は,「慰め」 機能を反映していると考えられる。「慰め」は「感情 調節」が分離したものと捉えることもできる。実際に 両者の間には中程度の因子間相関（.422）があった。

Saarikallio（2012）も慰めが音楽聴取による気分調整 方略の 1 つであるとしている。ここで「感情調節」因 子と「慰め」因子の違いについて考えてみると, 一般 に感情調節は感情が生じる前に行う先行焦点型と, 感 情が生じた後で行う反応焦点型に大別できる（Gross， 1998）。「感情調節」因子は主にポジティブな感情状態 を指向して音楽を聴く先行焦点型の感情調節であるの に対し，「慰め」因子は落ち込んだ気分が生じたこと に対する反応焦点型の感情調節であるという点で異な ると考えられる。三枝（2020）によれば，第二次世界 大戦前には娱楽として多く聴かれた軽音楽は, 開戦直 後に全く聴かれなくなり, 敗戦色が強まると慰安音楽 として再び多く聴かれるようになった。これは，個人 を取り巻く社会の状況によって軽音楽の機能形態が 「感情調節」から「慰め」に変化したことを示す知見 であると考えられる。

個人差については，まず女性は男性よりも「慰め」 機能を強く認識していた。女性は個人的な悲しい出来 事を想起すると男性よりも強い悲しみを感じ（Hess et al., 2000), ストレス状況において男性よりも情緒的な サポートを希求する傾向にある（佐々木・山崎, 2002)。このような特性により音楽聴取の「慰め」機 能を活用しやすいものと推察される。パーソナリティ については情緒不安定性との関連が示された。情緒不 安定性の高い個人はネガティブ感情を経験することが より多いため,「慰め」機能を享受しやすいものと考
えられる。

\section{日本における音楽聴取の心理的機能}

以上にみてきたように，音楽聴取には自己理解や自 己形成を促したり，心身の状態を整えたり，他者と自 己との間に適切な距離をとりつつも, 良好な関係構築 に貢献したりするような機能をもっており，時として 人は目下の目的を達成するための道具としても音楽聴 取を活用する。このように考えると，音楽聴取は人が より適応的, 健康的に生きる上で役立ちうるような多 様な機能を持ち併せているといえるだろう。Lonsdale \& North（2011）は，他の余暇活動と比べて音楽聴取 が個人のニーズに対しより高く評定されたことを報告 し，その様子を「万能性」と表現した。本研究では音 楽聴取と他の活動との比較は行っていないものの, 本 研究で抽出されたような音楽聴取の多様な機能が, こ のような万能性を支えているのかもしれない。

\section{今後の展望}

本研究は調査法により音楽聴取の心理的機能につい て回答者に尋ねた。そのため得られたデー夕は，音楽 聴取の心理的機能における言語化可能で意識的な側面 に焦点が当てられている。したがって，音楽聴取の非 言語的で意識下の機能については焦点が当てられてい ないことには注意が必要であろう。

日本人の音楽聴取における心理的機能は大きく 7 つ の因子に整理され，そのうちほとんどは先行研究で見 出されたものと共通の内容と解釈された。しかし，西 欧での研究では見出されなかった独自の因子かもしれ ない「社会的距離調節」因子が抽出されたのは興味深 い。今後はこの機能の実在性を異なる研究手法でも検 証していく必要があるだろう。さらに, 各因子（機能） は, 聴取者の性別, 年齢, パーソナリティといった個 人属性によってそれが働く強さに相違が示された。 個々人は同時にいくつかの，異なるが相互連関する機 能を自らの多様な状況や欲求に合わせて実現している といえるだろう。さらに今後の課題として, 聴取者の おかれた環境（たとえば出身地や居住地）, 音楽経験 の多少, 普段よく聴取するジャンルや好みの程度など が心理的機能に与える影響についても調べる必要があ るだろう。

また, 本研究では聴取以外の音楽的行動（たとえば 歌唱, 演奏, 作曲) についての検討や比較は行ってい ない。そのため本研究で見出された機能が，どこまで が音楽聴取独自のものであるかについては, 留意が必 要である。

人間は時代や場所にかかわらず音楽を聴いてきた。 音楽に関する学術研究は, 音楽学や心理学に限らず, 社会学, 神経科学, 工学, 医学など様々な領域に及ん でいる。音楽聴取の心理的機能を明らかにしていくこ 
とは, 人間の音楽的行動に関する学術研究を行うこと の意義にも繋がる重要なテーマであると考えられ，今 後も知見が蓄積されていくことが望まれる。

\section{利益相反}

本文に関して, 開示すべき利益相反関連事項はない。

\section{引用文献}

Barrett, L. F., Lane, R. D., \& Schwartz, G. E. (2000). Sex differences in emotional awareness. Personality and Social Psychology Bulletin, 26, 1027-1035.

Boer, D., \& Fischer, R. (2011). Towards a holistic model of functions of music listening across cultures: A culturally decentred qualitative approach. Psychology of Music, 40, 179-200.

Brody, L. R., \& Hall, J. A. (2010). Gender and emotion in context. In M. Lewis, J. M. Haviland-Jones, \& L. F. Barrett (Eds.), Handbook of emotions (3rd ed., pp.395408). New York: The Guilford Press.

Brose, A., Scheibe, S., \& Schmiedek, F. (2013). Life contexts make a difference: Emotional stability in younger and older adults. Psychology and Aging, 28, 148-159.

Chamorro-Premuzic, T., \& Furnham, A. (2007). Personality and music: Can traits explain how people use music in everyday life? British Journal of Psychology, 98, 175185.

Clayton, M. (2016). The social and personal functions of music in cross-cultural perspective. In S. Hallam, I. Cross, \& M. Thaut (Eds.), The Oxford handbook of music psychology (pp. 47-59). Oxford: Oxford University Press.

Gross, J. J. (1998). The emerging field of emotion regulation: An integrative review. Review of General Psychology, 2, 271-299.

Hays, T., \& Minichiello, V. (2005). The meaning of music in the lives of older people: A qualitative study. Psychology of Music, 33, 437-451.

Hess, U., Senécal, S., Kirouac, G., Herrera, P., Philippot, P., \& Kleck, R. E. (2000). Emotional expressivity in men and women: Stereotypes and self-perceptions. Cognition and Emotion, 14, 609-642.

星野 悦子 (2015). 音大生の日常音楽聴取行動と性格 一一背景音楽の利用, 選好音楽ジャンルと Big Five 次元の関連性——本心理学会第 79 回大 会発表論文集, 47.

John, O. P., \& Gross, J. J. (2006). Individual differences in emotion regulation. In J. J. Ekman (Ed.), Handbook of emotion regulation (3rd ed., pp.351-372). New York: The Guilford Press.

Juslin, P., \& Västfjäll, D. (2008). Emotional responses to music: The need to consider underlying mechanisms. Behavioral and Brain Sciences, 31, 559-621.

Kamenetsky, S. B., Hill, D. S., \& Trehub, S. E. (1997). Effects of tempo and dynamics on the perception of emotion in music. Psychology of Music, 25, 149-160.
Lonsdale, A. J., \& North, A. C. (2011). Why do we listen to music? A uses and gratifications analysis. British Journal of Psychology, 102, 108-134.

Luck, G., Saarikallio, S., Burger, B., Thompson, M. R., \& Toiviainen, P. (2010). Effects of the Big Five and musical genre on music-induced movement. Journal of Research in Personality, 44, 714-720.

Madison, G. (2006). Experiencing groove induced by music: Consistency and phenomenology. Music Perception, 24, 201-208.

Merriam, A. P. (1964). The anthropology of music. Evanston, IL: Northwestern University Press.

（メリアム, A. P. 藤井 知昭・鈴木 道子（訳） (1980). 音楽人類学 音楽之友社)

Millgram, Y., Joormann, J., Huppert, J. D., \& Tamir, M. (2015). Sad as a matter of choice? Emotion-regulation goals in depression. Psychological Science, 26, 12161228.

Miranda, D. (2013). The role of music in adolescent development: Much more than the same old song. International Journal of Adolescence and Youth, 18, 5-22.

North, A. C., Hargreaves, D. J., \& O'Neill, S. A. (2000). The importance of music to adolescents. British Journal of Educational Psychology, 70, 255-272.

小塩 真司 (2010). はじめて学ぶパーソナリティ心理 学ミネルヴァ書房

小塩 真司・阿部 晋吾・カトローニ, ピノ (2012). 日本語版 Ten Item Personality Inventory（TIPI-J) 作成の試み パーソナリティ研究, 21, 40-52.

Rentfrow, P. J., \& Gosling, S. D. (2003). The do re mi's of everyday life: The structure and personality correlates of music preferences. Journal of Personality and Social Psychology, 84, 1236-1256.

Saarikallio, S. (2012). Development and validation of the brief music in mood regulation scale (B-MMR). Music Perception, 30, 97-105.

三枝まり (2020). 番組名から見る戦前期の洋楽放送 一JOAKを中心に一—上野学園創立 115 周年 記念論文集， 57-69.

佐々木 恵・山崎 勝之 (2002)。コーピング尺度 (GCQ) 特性版の作成および信頼性・妥当性の検討 日本 公衆衛生誌, 5, 399-408.

Schäfer, T., Seldmeier, P., Städtler, C., \& Huron, D. (2013). The psychological functions of music listening. Frontiers in Psychology, 4, 511. https://doi.org/10.3389/ fpsyg.2013.00511

Schäfer, T., Tipandjan, A., \& Sedlmeier, P. (2012). The functions of music and their relationship to music preference in India and Germany. International Journal of Psychology, 47, 370-380.

Selfhout, M. H. W., Branje, S. J. T., ter Bogt, T. F. M., \& Meeus, W. H. J. (2009). The role of music preferences in early adolescents' friendship formation and stability. Journal of Adolescence, 32, 95-107.

総務省統計局（2017）。平成 28 年社会生活基本調査結 果 Retrieved from https://www.stat.go.jp/data/ shakai/topics/pdf/topics105.pdf（2020 年 3 月 28 日）

Trapnell, P. D., \& Campbell, J, D. (1999). Private self-con- 
sciousness and the five-factor model of personality: Distinguishing rumination from reflection. Journal of Personality and Social Psychology, 76, 284-304.

Vuoskoski, J. K., Thompson, W. F., McIlwain, D., \& Eerola, T. (2012). Who enjoys listening to sad music and why? Music Perception, 29, 311-317.

Wrzus, C., Hänel, M., Wagner, J., \& Neyer, F. J. (2013). Social network changes and life events across the life span: A meta-analysis. Psychological Bulletin, 139, 53 -80 .

山本 七平 (1977). 「空気」の研究 文藝春秋

Zatorre, R. J. \& Peretz, I. (2001). The biological foundations of music. New York: New York Academy of Sciences.

- 2020.4.16 受稿, 2021.5.1 受理 